\title{
The Relationship between Commitment-based HR Practices and Organizational Performance: The Role of Organizational Learning Capabilities as a Mediator
}

\author{
Po Li Chia, Khulida Kirana Yahya, Tan Fee Yean \\ Universiti Utara Malaysia, Sintok, Kedah, Malaysia \\ pollychia29@yahoo.com
}

\begin{abstract}
This study intends to investigate the relationship between commitment-based human resource practices (CBHRP) and organizational performance of the multi-national organizations in Malaysia with the present of organizational learning capability (OLC) as the mediator. The data were collected from 150 multinational organizations, using a survey questionnaire. The returned response rate was 97 percent. A relevant statistical analytical such as regression analysis was used to test the hypotheses set forth in this study. The outcome of the analysis showed that the relationship between commitment-based HR practices and organizational performance was influence by organizational learning capability. The results imply that the multi-national organizations should enhance their CBHRP and OLC to strengthen their organizational performance.
\end{abstract}

Keywords: Organizational performance, Commitment-based human resource practices, Organizational learning capability

\section{Introduction}

Multinational (MNC) organizations in Malaysia play an important strategic role in Malaysia to foster economy growth enrich the job opportunity and increasing income (MIDA, 2012). Accordingly, the primary of MNCs in Malaysia is based on semiconductor industries, which handle electronics application products for consumer and industrial market. The contribution of semi-conductors MNCs owns the largest share of export value, which was 51 percent, compared to other sub-industries. It has also provided 41 percent of employment opportunity in the country (MIDA, 2014). According to Malaysia Investment Performance 2013 (MIDA, 2014), there was 118 Electronics and Electric (E\&E) projects approved in 2013 that worth RM9.8 billion in the investment. The biggest investment came from Japan (45 percent) follow by United States of America (35 percent) and Germany (20 percent). This investment showed that the establishment of MNCs organizations in the country is valuable as they can boost the growth of Malaysia economic.

Unfortunately, the MNCs organizations contribution to the country GDP is still somewhat lacking compared with other developed countries. MNCs in Thailand are 4.9 percent while MNCs in Indonesia productive grew by 4.2 percent which better than Malaysian MNCs which only 1.96 percent (MPC, 2013). Besides this, the current volatile external environment and escalating global competition have forced the MNCs organizations to be more flexible their management and business strategies to survive and perform. Additionally, MNC's organization is moving towards the phase whereas the shortfall of skillful, knowledge and experience employees are the major concerned (Raida, 2009; Fathi, Mohmad \& Kamal, 2013). As a result, this shortfall (e.g. knowledge, skill and experience employees) becomes a hinder for MNCs in Malaysia to retain their human resources for continuous growth and achieve better performance. According to Fathi, Mohmad and Kamal (2013) human resources asset (i.e. skill, knowledge and experience) are recognized as strategic tools that are essential to drive the organization to achieve higher performance.

\section{Literature review}

The key to achieving higher performance, organizations must be flexible and adapt quickly to market demand, help diversify economic activity through export and trade activities and enhance human resources development. Nonetheless, the primary objective of this study is to give attention to the importance of human resources development to unleash the organizational performance. Specifically, this paper intends to shed light on human resource management's (HRM) contribution to the performance of MNCs organization by 
investigating the OLC (organizational learning capability) stands as a mediator role between commitmentbased HR practices and organizational performance.

The significant role of HRM in assisting the organization to achieve best performance has gained lot of attention to both researchers and human resource practitioners. This is agreeable by many scholars like Batt (2002), Becker and Huselid (1998), Collins and Clark (2003), Lopez et al. (2005) and Takeuchi et al. (2007). The scholars in their research has offered significant proof that human resources practices especially those known as 'high performance' or 'commitment-based' can influence employees' abilities and motivation and thus organizational performance. Nevertheless, the relationship tends to be relatively small in statistical terms (Lopez et al., 2005). Similarly, studied by Hooi and Ngui (2014) showed that the relationship between HRM and organization based line of performance did not offered direct cause-effect path. Meanwhile, other scholars like Youndt et al. (1996) cited that when HR practices create value and deliver results for the organization automatically the relationship between HRM and organizational performance is established. Thus, the question arises in the literature whether HRM can stand along to influence organizational performance or they must reinforce with other variables. More specifically, which individual HR practices and other variables have an exact influence on the organizational performance measures? These questions have urged many researchers to refine the existing theoretical models by including other mechanisms to strengthen the relationship between commitment-based HR practices and organizational performance.

Therefore, many researchers' have attempted to articulate this linkage by analyzing how HRM impact organizational progress since there was the lack of any theoretical explanation. Researchers like Lopez et al. (2005), Raj and Srivastava (2013) and Watkins and Marsick (1992) cited that certain HR practices have its ability to enhance the learning process of individual, group and organization level. To support this argument, scholars like Snell et al. (1996) and Jerez-Gomez et al. (2005) in their research found that HR practices such as selection, compensation and training and development served as a driver to orientate employees' behavior as well as motivation and thus influence their learning attitudes in the organization. Likewise, Lopez-Cabrales et al. (2011) and Jerez-Gomez et al. (2005) points out those employees contribute to learning when they notice that their organization gave full attention to their needs into account, value their contribution and commitment. The findings showed that it is essential to design HR practices that encourage employees to be competitive through cooperation and capabilities and subsequently, assist the organization to achieve its best performance. Nevertheless, this mediation effects has yet fully explored by the former researchers.

Subsequently, the development of organizational learning capability is essential due to capabilities to business success and to create as well as delivering commitment-based HR practices that able to act as the fundamental of competitive advantage (Hooi \& Ngui, 2014; Lopez et al., 2006; Snell et al., 1996). Organizational learning capability is regarded as the fundamental source because through the learning process; the new knowledge can be acquired, create and transfer into the daily organizational process (JerezGomez et al., 2005). When new insights (e.g. knowledge) interact with its environment, it makes the organization to understand deeper of its own strengthen and weakness and subsequently, helps the organization to pursue new business strategies that change, move and act faster than their competitors. Furthermore, organizational learning capability process helps the employees able to focus on the deliverables of their work to enhance the organizational performance continuously (Cavaleri, 2004, Jerez-Gomez et al., 2005, Hooi \& Ngui, 2014, Lopez et al., 2006).

This present study proposes that the role of organizational learning capability mediate the relationship between commitment-based HR practices and organizational performance of MNC organizations. Despite their importance to the economic growth, high income, the diffusion of innovation and job creation, researcher concede that MNC organization in the country need to implement proactive HRM practices to enhance the organizational learning capability for sustained competitive advantage as well as improving organizational performance. Thus, researcher set out to validate the relationship. Before precede with the next step, the researcher reviews the literature on the impact of commitment-based HR practices on organizational learning capability and the effect of organizational learning capability on organizational performance. Following this, the researcher develops hypotheses representing the relationships between commitment-based HR practices, organizational learning capability and organizational performance. 
Subsequently, the researcher present the results gathered from statistical analysis and follow with the implications and conclusion.

Organizational Performance: Organizational performance (OP) is a tool that an organization uses to gauge its performance in terms of meeting the overall objectives and goals (Gharakhani \& Mousakhani, 2012, Hamon 2003). In a case of Folan and Browne (2005) and Ho (2008), the scholars' definition of OP by looking at how closes the organization able to achieve its overall business and management objectives. Meanwhile, other authors like Abu et al. (1989), Birdi et al. (2008), Davis et al. (2000) and Moideenkutty et al. (2011) postulated that OP should be measured from financial perspective (e.g. sales growth, net profit, profit growth and so on). However, Schermerhorn et al. (2002) argued that just measuring finance performance is insufficient. It should also be looked at the overall performance, which includes non-financial performance such quality and quantity of individual productivity, services, good image of the organization. However, Delaney and Huselid (1996) stated that it would be better to assess organizational performance from external and internal perspective. The external perspective refers to organization performance in the market that covered the marketing of products or services, growth of sales, profitability, and market share. As for the internal perspective focus on its performance against the quality of the product, a satisfaction of the customers, new product development, ability to attract employees, ability to retain employees and relations between management and employees.

Burns and McKinnon (1993) pointed out that to measure organizational performance should include the financial and non-financial perspectives. By doing so, it is fair to the organization as a combination of a different perspective of measuring OP offers ways to transform strategies that end of the day benefit the organizations. Additionally, it provides a protection against the consequences of unforeseen outside events that may affect the organizational performance. Therefore, following the literature review, this study adapted to the suggestion by Delaney and Huselid (1996) to measure overall OP by defining OP as organization external and internal performance.

Commitment-based HR practices: HRM in today's management context has two distinguished roles: (1) to foster performance of an organization (Stavrou, Brewster \& Charalambousa, 2010; Delery \& Doty, 1996; Nazlina, SitiRohaida \& Aizzat, 2011; Singh, 2004; Zheng, O'Neill \& Morrison, 2009) and (2) to act as a support for achieving competitiveness through people (Collins \& Smith, 2006; Huselid, 1995; Muhammad Asif, 2010; Wright, Dunford \& Snell, 2001). In this regard, the focus shifted to the choice of HRM practices to be implemented in the organization. According to Arthur (1992), Bourne et al. (2013), Collins \& Smith (2006) and Tsui et al. (1995), two HRM practices have emerged in the literature: 1) emphasizes on the individual short-term exchange relationships which were known as transaction-based HR practices and 2) focuses on long-term exchange and mutual relationship which known as commitment-based HR practices (CBHRP). Accordingly, in the literature, CBHRP has been regarded as the best solution due to its combination of practices that able to attract the employees' to display positive behaviors as well as combining their personnel and organization interest together (Arthur, 1992; Collins \& Smith, 2006). To support this motion, many empirical evidences have showed organizations which implement CBHRP influence organizational performance better than transaction-based HRM practices (Batt, 2002; Bourne et al., 2013; Collins \& Smith, 2006; Huselid, 1995; Youndt et al., 1996).

Collins and Smith (2006) and Bourne et al. (2003) cited that the used of HR practices to create commitmentbased atmosphere is varies across organizations. Fortunately, they agreed that three specific dimensions of HR practice that results commitment-based environment as follows;

- Selection practices emphasizes on the opportunity of internal employment and selecting employees who match the organization set forth criteria instead of specific job requirements.

- Compensation practices by all means emphasize on enhancing employees' commitment and thus encourage them to accomplish the given tasks effectively for the purpose to achieve the set forth objectives and goals by the organization.

- Training and development practices by all means focus on improving and development of the organization specific knowledge and skills as well as team building. 
Based on the definition as mentioned above, this study analyses the relation between CBHRP (selection, compensation and training and development) and organizational performance as well as organizational learning capability. The next section discuss in details of each dimension of CBHRP.

Selection: The definition of selection in CBHRP focuses on selecting the internal employees to fill in the vacant position in the organization (Bourne et al., 2003; Collins \& Smith, 2006). Additionally, selection process also involves collection, measuring and evaluating information of the selected candidates (Marwat, Arif \& Jan, 2009). By doing so, it ensures that the right candidates are being assigned to the positions where they can perform efficiently and effectively. This process, it enables the organization to select candidate who meet the criteria that had been set forth. The closer the candidates who possess the characteristics of the organization's need, the higher their chances of being chosen to fill up the vacant position. Furthermore, when the best candidates are hired, it will potentially increase the productivity and boost organizational performance (Huselid, 1995). In the simple words, selecting the right employees able the organization to go through the unpredictable environment derived from external or internal factors. It is also helps the organization to response and act faster in order to stay ahead in the competitive market. Therefore, organization needs to acknowledge that human resources are the significant assets in the organization due to their ability to enhance the organization reputation for the long term and ensure its future success.

Compensation: The definition of compensation in CBHRP emphasize on the incentive package offered to the employees to increase their commitment (Bourne et al., 2003; Collins \& Smith, 2006). This is agreeable by (Noe, Hollenbeck, Gerhant \& Wright, 2004) who cited that compensation originally designed to motive employees to increase their outputs towards achieving organizational objectives and goals. Additionally, the compensation also plays the role to attract and reward the employees who have put up extra efforts to achieve organization's set forth targets. Hence, compensation plays a key role as it is connected with employment relationship to both employers and employees. There is no deny that employees depends largely on the salaries and other financial benefits be it in terms of finance or non-finance to provide income for daily needs (Trevor, Barry \& Boudreau, 1997). In addition, compensation also has the influence on employee attitudes and behaviors towards their organization (Phillips, 1997). For employers, compensation is one of the significant impacts on the business operation costs and thus, their ability to increase the organizational performance.

Training and Development: The training and development as defined in CBHRP emphasis on upgrading the needed knowledge and skills as well as strengthen team building in the organization. Specifically, the training process focus on acquires new knowledge and skills then migrate into the daily tasks assigned to the employees. In accordance to Armstrong (2006) stated that "is the use of systematic and planned instruction activities to promote learning". Sisson and Storey (2000) argued that employee perceive training as a symbol of employer's commitment towards them. In regard to the development process, it offers an opportunity to upgrade their position in the organization and accept the new responsibility, job tasks and so on. Similarly, Noe et al. (2004) reiterate that it is necessary for the organization to provide the development opportunity to their employees so that offer ways to improve the quality of job performance which benefit the organizations in the long term. In a summary, if the organization is able to develop a training program which tie up with the development of skills needed, it is likely to result a higher organization performance derive from the productivity and efficiency factors.

Organizational Learning Capability: The ability of the organization to create, acquire and blend the knowledge is known as organizational learning capability (OLC) that emphasis on enrich the resources and develop the capability in the organization (Jerez-Gomez et al., 2005). Likewise, Goh et al. (2012) see OLC as a continuous learning process for steady improvement to help the organization to succeed. This concludes that OLC is a process to increase employee's capabilities for better understanding and managing the organization's environment in order to increase organizational performance and thus, gives the opportunity for the organization to increase its learning capability and thus, enhance its ability to exercise the appropriate management practices, structures and procedures (Jones, 2000; Mohd Shamsul et al., 2011). Based on the above, it is obvious that OLC serves as the capability of an organization to create, acquire, transform and blend knowledge among organization members helps organization to achieve its best performance. To enhance the development of OLC, Jerez-Gomez et al. (2005) cited that the emphasis should be given to the 
aspects such as commitment from the managerial level, the uphold appropriate systems (e.g. management system or procedures), practicing of the openness and experimentation by the organization and lastly, the capability to transfer and integration the knowledge from the learning capability. It has been assumed that each dimensions of the OLC will result in a stronger learning capability throughout the organizations.

\section{Research model and hypotheses}

Commitment-based HR practices and Organizational learning capability: In the literature, it has been widely acknowledged that HRM practices are the determined factor in strengthening organizational learning capability (OLC) in the organization. The management can develop stronger commitment by employees through implement of distinctive HR practices to boost learning process at all levels in the organization (Hooi \& Ngui, 2014; Minbaeva, 2005). Also, HR practices are useful to promote positive behaviors towards OLC and make it as habitual for people to sharpen their skills and develop right attitudes to promote learning (Raj \& Srivastava, 2013; Swart \& Kinnie, 2010). Therefore, to strengthen OLC, the first step is to increase the employees and organizational levels commitment through HR practices (Hooi \& Ngui, 2014; Minbaeva, 2005). Specifically, the component in commitment-based HR practices (e.g. selection, compensation and training and development) can support OLC either individual or organization levels (Collins \& Smith, 2006). Selection practices ensure internal employees are given the opportunity to fill up the vacant position in the organization. The organization will use formal selection procedure to ensure the organization chooses the suitable candidates for the vacant positions and thus, they can perform efficiently and effectively. When the internal employees are given the promotion opportunity, this increases their motivation and commitment as they feel their management value their contribution and efforts in the organization. As a result, it leads to better performance in the organization. Compensation practices that offer attractive rewards to the employees who continuously enhance their knowledge and skills lead to high motivation and commitment. Consequently, it makes OLC as learning habit in their daily working process (Bourne et al., 2013; Collins \& Smith, 2006). Subsequently, to enhance OLC, the organization has to invest in enhancing their training and development program to assist the employees to improve their knowledge and skills. By doing so, it enables the employees to improve their job performance to meet up with the organization set forth objectives (Raj \& Srivastava, 2013). Noticing the potential commitment-based HR practices to influence OLC, the first proposed hypothesis as follows,

H1: Commitment-based HR practices have a positive influence on organizational learning capability.

Commitment-based HR practices and Organizational performance: In the literature, many past studies have largely proven the significant influence of commitment-based HR practices (CBHRP) on increasing the performance of organizations (Chen \& Huang, 2009; Lopez-Cabrales et al., 2005; De Winne \& Sels, 2010). CBHRPs aim to implement various HR practices that work together to increase employee motivation and enhance their commitment to the organization (Ghosh \& Gurunathan, 2015). When the employees are highly motivated and committed, they usually deliver high-quality performance and enable the organization to perform better. CBHRP consists of selection, compensation and training and development practices. Selection practices emphasize on the internal labor market and identifying the competent employees to fill in the vacant position in the organization (Bourne et al., 2013; Collins \& Smith, 2006).

By doing so, it assists to establish stronger employer-employee relationship which in turn increasing their productivity and commitment (Collins \& Smith, 2006; Ghosh \& Gurunathan, 2015). The employees who are usually committed more productive and thus enhance the productivity of the organizations. Consequently, affects the organizational performance. Compensation practices focus on an incentive package to motivate the employees to utilize their knowledge and skills for better efficiency, increase motivation and commitment. By doing so, the employees can fulfill the organizations set forth objectives as well as goals (Collins \& Smith, 2006; Delaney \& Huselid, 1996; Jerez-Gomez et al., 2005). Training and development practices emphasis on enhancing the employees' ability to migrate the knowledge and skills into their daily job and thus, increase organizational performance (Collins \& Smith, 2006; Lopez et al., 2005). These studies have proven that the organizations need to strengthen their commitment-based HR practices as it results in significant improvement of organizational performance. Following these findings, the proposed hypothesis is:

H2: There is a positive relationship between commitment-based HR practices and organizational performance. 
Organizational learning capability and Organizational performance: Numerous studies in the literature showed that organizational learning capability (OLC) has significantly influenced all members of the organizations of their learning capability. It also serves as essential criteria of enriching the organization resources and capacities to enhance its performance for the long term (Egan et al., 2004; Lopez et al., 2005; Sony \& Naik, 2012). OLC given the attention on the process to recruit, create, transform and integrate the knowledge aimed to achieve greater performance in the organization. When the new insights migrate into an organization, it enables the organization to act quickly than its rivals. Consequently, it creates a strategic advantage in response to the fierce competition in the market (Cavaleri, 2004; Lopez et al., 2005; Weldy \& William, 2010). As a result, it strengthens the performance of the organization. To develop stronger OLC, Jerez-Gomez et al. (2005) proposed that OLC must deal with four criteria which are (1) the commitment from the managerial in the organization, (2) all members of the organization must share same perspective, (3) an open mind culture should be practice in the organizations and (4) to be more flexible in adopting new knowledge or ideas and blend into the organization daily practices. Based on these four criteria, many researchers have regarded OLC as a multidimensional construct since it develops a culture that promotes the acquisition, creation and transfer of knowledge as the core values for the organizations (Goh et al., 2012). Hence, organizational learning capability has been regarded as the strong influence factor of the organizational performance with some empirical studies providing evidence of a positive effect between these two variables (Flores et al., 2008; Jones, 2000; Lopez et al., 2006; Spicer \& Sadler-Smith, 2006; Wang, 2008). Thus, the third hypothesis is that:

H3: Organizational learning capability influences the organizational performance.

Commitment-based HR practices, Organizational learning capability and Organizational performance: The positive relationship between commitment-based HR practices (CBHRP) and organizational learning capability (OLC) on the organization's productivity and performance have been reported in numerous studies (e.g. Batt, 2002; Lopez-Cabrales et al. 2011; Camps \& Luna-Arocas, 2010; Garavan et al., 2002; Jaw \& Liu, 2003; Lopez et al., 2005; Raj \&Srivastava, 2013; Theriou \& Chatzoglou 2008). Basically when OLC exists in the organization, it enables the employees to learn when they have the knowledge and abilities that the organization requires (Gupta \& Govindarajan, 2000; Rhodes et al., 2008) and CBHRP may influence the organizational learning capability by enhancing the organization competencies which may assist the organizations to achieve its best performance (Goh et al., 2012; Lopez et al., 2006). This is to say that the management needs to implement specific HR practices such as commitment-based HR practices to give support to the organizational learning capability process inside the organization. Collins and Smith (2006) cited that to ensure OLC well operating, the management must gather stronger commitment from their employees. They further added that CBHRP (selection, compensation and training and development) are able to support OLC either individual or organization levels. CBHRP focuses on long-term exchange and mutual relationship for all members in the organizations. Furthermore, CBHRP has its own capability to attract the employees' due to its specific practices that aim to encourage the employees to display positive behaviors and attitudes. Additionally, it also increases the motivation of the employees to work as one identity for benefit of altogether (Arthur, 1992; Collins \& Smith, 2006).

Furthermore, the literature has suggested that CBHRP have the high ability to shape the employees attitudes and behavior, and thus it plays a pivotal role towards the success of OLC (Collins \& Smith, 2006; Shipton et al., 2002). This can be achieved in several ways. For an example, CBHRP that an organization may encourage the learning process to begin from the selection practices. Through the selection process, the organization can select the candidate internally who possess the right knowledge and skills accustomed with strong desired to enhance their personal and organizational learning capability (Jerez-Gomez et al., 2005; Hooi \& Ngui, 2014). To encourage both types of learning process, the organizations have to invest in their training and development program for the purpose to enhance employees' capabilities as well as performance for strengthening the organizational productivity and performance (Jerez-Gomez et al., 2005; Raj \& Srivastava, 2013; Shipton et al., 2002). Compensation practices which inclusive of intensive will enhance employee's attitudes and thus, lead a cooperative behavior and motivate them to look for new knowledge and skills. When the employees are motivated to upgrade themselves, it enhances the OLC process in the organizations (Jerez-Gomez et al., 2005; Kang et al., 2007). Therefore, this present study, CBHRP is regarded as key role in strengthening OLC in the organization. The organization that achieved high OLC enable to withstand the volatile business environment and sustain its performance. By having high OLC, employees are able to 
enhance their abilities to support the organizations to face any challenge derived from internal and external factor. Consequently, it increases the organizational performance (Lopez et al., 2005). Hence, the next hypothesis is proposed

H4: The relationship between commitment-based HR practices and organizational performance mediates by organizational learning capability.

Following the discussion of the literature as above and the hypotheses set forth in this study, the research model as shown in the figure 1.

\section{Figure 1: Research Model}

Commitment-Based HR

Practices

Selection

Compensation

Training \&

Development



\section{Methodology}

Data collection and sample: This study used a survey questionnaire method for data collection to test the hypotheses. The questionnaires are divided into two parts whereas first part is for background information while second part consists of the variables such as commitment-based HR practices (CBHRP), organizational learning capability (OLC) and organizational performance. The independent and mediation variables used seven-point Likert style ranged from 'strongly disagree to 'strong agree' while dependent variable used fivepoint Likert style also ranged from 'strongly disagree' to 'strongly agree.' This study examined a sample of 150 multi-national organizations in Malaysia. A representative of the organizations (e.g. HRM managers) who has the sufficient capacity has been chosen to complete the questionnaires. Of the 150 completed questionnaires, seven are incomplete. As a result, it is only 143 valid completed questionnaires to be used for the next statistical analysis.

\section{Findings}

Reliability: Cronbach alpha $(\alpha)$ method is used to check the reliability of the measurements in the survey as well as to gauge the internal consistency of the questionnaires items. According to Sekaran (2000) the minimum recommended level of 0.60 or higher can be regarded as the criterion of internally consistent established factors. The commitment-based HRM practices consists of selection 4 items $(\alpha=0.753)$, compensation 4 items $(\alpha=0.885)$ and training and development 8 items $(\alpha=0.764)$. The organizational learning capability factor consists of ten items $(\alpha=0.774)$. The organizational performance factor consists of ten items $(\alpha=0.760)$.

Means, Standard Deviations and Correlations: This study intends to investigate the relationships between commitment-based HR practices, organizational learning capability and organizational performance. Table 1 illustrated the means, standard deviations and correlations result of all variables.

Table 1: Means, standard deviations and correlations

\begin{tabular}{llllllll}
\hline Constructs & Mean & S.D. & $\mathbf{1}$ & $\mathbf{2}$ & $\mathbf{3}$ & $\mathbf{4}$ & $\mathbf{5}$ \\
\hline 1. Sel & 3.93 & 0.78 & 1.00 & & & & \\
2. Com & 3.86 & 0.76 & $0.54^{* *}$ & 1.00 & & & \\
3. T\&D & 3.83 & 0.73 & $0.58^{* *}$ & $0.64^{* *}$ & 1.00 & & \\
4. OLC & 4.02 & 0.83 & $0.77^{* *}$ & $0.67^{* *}$ & $0.53^{* *}$ & 1.00 & \\
5. OP & 3.68 & 0.89 & $0.44^{* *}$ & $0.58^{* *}$ & $0.59^{* *}$ & $0.69^{* *}$ & 1.00 \\
\hline
\end{tabular}

Note: Significant at: ${ }^{*} \mathrm{p}<0.05$ and ${ }^{* *} \mathrm{p}<0.01$

Sel=Selection; Com= Compensation; $\mathrm{T} \& \mathrm{D}=$ Training \& Development; OLC=Organizational learning capability; $\mathrm{OP}=$ Organizational Performance. 
As depicted in Table 1 above, the findings of correlation analysis has shown positive relationships between commitment-based HR practices (selection, compensation and training and development) with organizational learning capability. This result showed that commitment-based HR practices leads to higher learning capability in the organization. The analysis also stated significant influence commitment-based HR practices with organizational performance. In addition, organizational learning capability also positive influences the organizational performance. Having a strong organizational learning capability enable the organization to sustain its competitiveness and directly affects organizational performance. Finally, the correlation between commitment-based HR practices and organizational learning capability on organizational performance also on the higher side, indicating that commitment-based HR practices and organizational learning capability are the essential tools to achieve greater organizational performance.

Correlation Analysis: The objective of the correlation analysis is to ensure the variables are tending to vary together or not. Table 2 illustrated the results of the correlation analysis and it showed the significant correlation (at the $\mathrm{p}<0.01$ level) between commitment-based HR practices and organizational learning capability. Therefore, the results support hypothesis H1. Next, hypothesis $H 2$ was tested between commitment-based HR practices and organizational performance. This result showed that organization is able to increase its performance if they have well developed the commitment-base HR practices. Therefore, $H 2$ is accepted. Additionally, to test hypothesis $H 3$, a correlation test was run between organizational learning capability and organizational performance and the relationship was found moderately support $H 3$. Thus, $H 3$ is accepted. Finally, Hypothesis $H 4$ is to test the mediation effect of organizational learning on the relationship between commitment-based HR practices and organizational performance. This result suggested that organizational learning capability has mediated the relationship. Therefore, hypothesis $H 4$ is acceptable.

Table 2: Correlation analysis results

\begin{tabular}{|c|c|c|c|}
\hline  & & $\begin{array}{l}\text { Organizational } \\
\text { Learning } \\
\text { Capability }\end{array}$ & $\begin{array}{l}\text { Organizational } \\
\text { Performance }\end{array}$ \\
\hline $\begin{array}{l}\text { Commitment-based } H R \\
\text { practices }\end{array}$ & Pearson Correlation & & \\
\hline Selection & & $0.25^{* *}$ & \\
\hline Compensation & & $0.27^{* *}$ & \\
\hline $\begin{array}{l}\text { Training } \quad \& \\
\text { Development }\end{array}$ & & $0.24^{* *}$ & \\
\hline $\begin{array}{l}\text { Commitment-based } H R \\
\text { practices }\end{array}$ & Pearson Correlation & & \\
\hline Selection & & & $0.31^{* *}$ \\
\hline Compensation & & & $0.40^{* *}$ \\
\hline $\begin{array}{l}\text { Training } \quad \& \\
\text { Development }\end{array}$ & & & $0.33^{* *}$ \\
\hline $\begin{array}{l}\text { Organizational } \\
\text { Learning Capability }\end{array}$ & Pearson Correlation & & $0.35^{* *}$ \\
\hline $\begin{array}{l}\text { Commitment-based } \\
\text { HRM practices }\end{array}$ & Pearson Correlation & $\begin{array}{l}\text { Organizational } \\
\text { learning capability }\end{array}$ & \\
\hline Selection & & (mediator) & $0.151^{*}$ \\
\hline Compensation & & & $0.40^{* *}$ \\
\hline $\begin{array}{l}\text { Training } \\
\text { Development }\end{array}$ & & & $0.28^{* *}$ \\
\hline
\end{tabular}

Regression Analysis: The purpose of the regression analysis was investigated whether the constructed model is significant or not. Subsequently, this test is also to calculate the total explained variance of the model of this study and also what percent of the organizational performance can be explained by commitmentbased HR practices and organizational learning capability. Therefore, from the model summary table 3 below indicates the statistical relationship between dependent variable (organizational performance) and independent variables (commitment-based HR practices and organizational learning capability). The results 
have showed the sufficient evidence that the research questions fit the measurement of the variables therefore it leads to the investigation of the model. The ANOVA result as per table 3 showed the model is significant (at the level of $\mathrm{p}<0.001$ ) and the commitment-based HR practices and organizational learning can explain $77 \%$ of the total variance of organizational performance.

Table 3: Regression analysis results

Model Summary

\begin{tabular}{lllll}
\hline Model & $\mathbf{R}$ & R Square & $\begin{array}{l}\text { Adjusted } \\
\text { Square }\end{array}$ & $\begin{array}{l}\text { Rtd. Error of } \\
\text { the Estimate }\end{array}$ \\
\hline 1 & $0.820^{\mathrm{a}}$ & 0.767 & 0.766 & 0.5781 \\
\hline
\end{tabular}

a Predictors: (Constant), Commitment-Based HR Practices and

Organizational Learning Capability

\begin{tabular}{|c|c|c|c|c|c|c|}
\hline \multicolumn{7}{|l|}{ ANOVA $^{b}$} \\
\hline Model & & $\begin{array}{l}\text { Sum } \\
\text { Squares }\end{array}$ & df & Mean Square & $\mathbf{F}$ & Sig. \\
\hline \multirow[t]{3}{*}{1} & Regression & 190.731 & 2 & 95.3655 & 0.575 & $0.000^{a}$ \\
\hline & Residual & 48.360 & 145 & 0.123 & & \\
\hline & Total & 239.091 & 147 & & & \\
\hline
\end{tabular}

bependent Variable: Organizational Performance

Discussion: This main purpose of this study is to examine the outcome of the relationship between commitment-based HR practices and organizational performance with organizational learning capability as a mediator. The findings indicated that the commitment-based HR practices emphasize on increasing employee commitment and influence on organizational learning capability, which is important for organizational performance. However, in the HRM literature, there is lack of strong evident linking HRM and organizational performance (Batt, 2002, Collins \& Clark, 2003; Hooi \& Ngui, 2014). This can be due to HRM practices do not affect the performance of organization either direct or indirect through other mediating variables and result affect organizational performance directly (Becker \& Huselid, 2006; Fleetwood \& Hesketh, 2006; Hooi \& Ngui, 2014). For example, Bourne et al. (2013) asserted performance measurement and HRM practices affect organizational performance while Gong et al. (2009) has investigated the relationship between performanceoriented HR subsystems and organizational performance by adding the managerial affective commitment as a mediator variable.

In this present study, organizational learning capability acts as the mediator in the relationship between committed-based HR practices and organizational performance. The rationale for choosing organizational learning capability is because 1) commitment-based HR practices aim to strengthen the employer-employees relationship, motivate employees and increase the commitment. The stronger commitment by the employees, the better it is for the organization to mobilize its knowledge and skill resources to achieve greater performance (Batt, 2002; Lopez-Cabrales et al., 2011; Camps \& Luna-Arocas, 2010; Garavan et al., 2002; Jaw \& Liu, 2003; Lopez et al., 2005; Raj \& Srivastava, 2013; Theriou \& Chatzoglou, 2008) and 2) organizational learning capability creates new competitive advantage in response to unpredictable business environment (Cavaleri, 2004; Lopez et al., 2005; Weldy \& William, 2010). As a result, it strengthens the organizational performance. Hence, results presented above supported the argument that the relationship between commitment-based HR practices, organizational learning capability and organizational performance is positive and organizational learning capability mediated the relationship between commitment-based HR practices and organizational performance. In a conclusion, the commitment-based HR practices and organizational learning capability play an important role towards improving the organizational performance.

Implications: The analysis result of this study has offered potential of implications for the organizations to consider for future management strategies to utilize it human resources for better organizational performance. Accordingly, it is suggested that the organizations should enhance its commitment-based HR practices and organizational learning capability into the organization day-to-day operations. The commitment-based HR practices are critical for human resource development as they enable the employer 
and employees establish a solid relationship and create a sense of belonging environment. In turn, it creates a positive attitude and thus establishes greater commitment and motivation levels. Having the sense of belonging, it encourages the employees to work even closely to achieve organization objectives and goals. A study by Delery and Doty (1996), Collins and Smith (2006), Huselid (1995) and Nazlina et al. (2011) proven that the commitment-based HR practices and organizational learning capability which well formulated by the organization may promote employees' motivation and commitment to pursue high organizational performance. From the findings, employees perceived the active efforts from the management to keep a good relationship between them tend to feel their contribution is worthwhile. Contrary to that, it allows employees to liberate their creativity and talents to the fullest and in turn, enhance the productivity.

\section{Conclusion}

In conclusion, it has indicated that the organizations are encouraged to utilize the HR practices for the reasons of 1) motivate and influence the employees attitude towards learning process, 2) to increase the desired of acquire new knowledge and skills, 3) accustomed with the desired to increase organizational learning capability and 4) to improve organizational performance. It is, therefore, important that organizations continuously deploy strategies that enhance the learning capability that connecting with the organizational objectives and goals. The findings are also important for practitioners and academics. This study has shed some lights of the importance of continuous improvement of commitment-based HR practices and organizational learning capability to achieve better organizational performance for the long term. Therefore, practitioners can use this result as a guideline to develop strategies to strengthen the organizational capability. Academics on another hand may use this result to understand deeper the roles of commitment-based HR practices and organizational learning capability and its impact on organizational performance.

\section{References}

Abu, K., Nor, A., Minai, B. \& Chun, L. S. (1989). Performance measures in Malaysia - the state of the art. Malaysian Management Review, 24, 3-9.

Arthur, J. B. (1992). The links between business strategy and industrial relations systems in American steel mini mills. Industrial and Labor Relations Review, 45, 488-506.

Armstrong, M. (2006). A hand book of human resource management practice. London: Kogan Page.

Batt, R. (2002). Managing customer services: Human resource practices, quit rates, and sales growth. Academy of Management Journal, 45, 587-597.

Birdi, K., Clegg, C., Patterson, M., Robinson, A., Stride, C. B., Wall, T. D. \& Wood, S. J. (2008). The impact of human resource and operational management practices on company productivity: a longitudinal study. Personnel Psychology, 61, 467

Becker, B. E. \& Huselid, M. A. (1998). High performance work systems and firm performance: a synthesis of research and managerial implications. Research in Personnel and HRM, 16, 53-101.

Becker, B. E. \& Huselid, M. A. (2006). Strategic human resources management: where do we go from here? Journal of Management, 32(6), 898-925.

Burns Jr., W. \& McKinnon, S. (1993). Information and managers: A field study. Journal of Management Accounting Research, 5, 84-108.

Bourne, M., Pavlov, A., Franco-Santos, M., Lucianetti, L. \& Mura, M. (2013). Generating organizational performance: the contributing effects of performance measurement and human resource management practices. International Journal of Operations \& Production Management, 33(11/12), 1599-1622.

Camps, J. \& Luna-Arocas, R. (2010). A matter of learning: How human resources affect organizational performance. British Journal of Management, 2, 1-21.

Cavaleri, S. A. (2004). Levering organizational learning for knowledge and performance. The Learning Organization, 11(2), 159-176.

Chen, C. J. \& Huang, J. W. (2009). Strategic human resource practices and innovation performance: The mediating role of knowledge management capacity. Journal of Business Research, 62(1), 104-114. 
Collins C. J. \& Clark, K. D. (2003). Strategic human resource practices, top management team social networks and firm performance: the role of human resource practices in creating organizational competitive advantage. Academy of Management Journal, 46(6), 740-751.

Collins, C. J. \& Smith, K. G. (2006). Knowledge exchange and combination: the role of human resource practices in the performance of high-technology firms. Academy of Management Journal, 49(3), 544560.

Davis, J. H., Schoorman, F. D., Mayer, R. C. \& Tan, H. H. (2000). The trusted general manager and business unit performance: empirical evidence of a competitive advantage. Strategic Management Journal, 21, 563576.

Delaney, J. T. \& Huselid, M. A. (1996). The impact of human resource management practices on perceptions of organizational performance. Academy of Management Journal, 39(4), 949-969.

Delery, T. J. \& Doty, H. D. (1996). Models of theorizing in strategic human resource management: tests of universalistic, contingency and configurationally performance predictions. Academy of Management Journal, 39(4), 802-835.

De Winne, S. \& Sels, L. (2010). Interrelationships between human capital, HRM and innovation in Belgian start-ups aiming at an innovation strategy. International Journal of Human Resource Management, 21(11), 1863-1883.

Egan, M., Yang, B. \& Bartlett, K. (2004).The effects of organizational learning culture and job satisfaction on motivation to transfer learning and intention. Human Resource Development Quarterly, 15(3), 539559.

Fathi, M. A. A. D., Mohmad, Y. S. \& Kamal, A. H. (2013). The causal relationship between HRM practices, Affective Commitment, Employee Retention and Organizational Performance. International Business Management, 7(3), 191-197.

Fleetwood, S. \& Hesketh, A. (2006). HRM-performance research: under-theorized and lacking explanatory power. The International Journal of Human Resource Management, 17(12), 1977-1993.

Flores, L., Catalanello, R., Rau, D. \& Saxena, N. (2008). Organizational learning as a moderator, of the effect of strategic planning on company performance. International Journal of Management, 25(3), 569-577.

Folan, P. \& Browne, J. (2005) A review of performance measurement: towards performance management. Computers in Industry, 56, 663-680.

Garavan, T. N., Morley, M., Gunnigle, P. \& McGuire, D. (2002). Human resource development and workplace learning: Emerging theoretical perspectives and organizational practices. Journal of European Industrial Training, 26(2/3/4), 60-71.

Gharakhani, D. \&Mousakhani, M. (2012). Knowledge management capabilities and SMEs' organizational performance. Journal of Chinese Entrepreneurship, 4(1), 35-49.

Ghosh, D. \& Gurunathan, L. (2015). Do commitment-based human resource practices influence job embededness and intention to quit? IIMB Management Review, 27, 240-251.

Goh, S. C., Elliott, C. \& Quon, T. K. (2012). The relationship between learning capability and organizational performance: a meta-analytic examination. The Learning Organization, 19(2), 92-108.

Gong, Y., Law, K. S., Chang, S. \& Quon, T. K. (2009). Human resource management and firm performance: the differential role of managerial affective and continuance commitment. Journal of Applied Psychology, 94(1), 263-275.

Gupta, A. K. \& Govindarajan, V. (2000). Knowledge management social dimension: lesson from Nucro Steel. Sloan Management Review, 42(1), 71-80.

Hamon, T. T. (2003). Organizational effectiveness as explained by social structure in a faith-based business network organization. Unpublished doctoral dissertation, Regent University, Virginia Beach, VA.

Huselid, M. A. (1995). The impact of human resource management practices on turnover, productivity and corporate financial performance. Academy of Management Journal, 38(3), 635-872.

Hooi, W. L. \& Ngui, S. K. (2014). Enhancing organizational performance of Malaysian SMEs: The role of HRM and organizational learning capability. International Journal of Manpower, 35(7), 973-995.

Ho, L. A. (2008). What affects organizational performance? The linking of learning and knowledge management. Industrial Management \& Data Systems, 108(9), 1234-1254.

Ho, T. C. F., Noor Hazlina, A. \& Thurasamy, R. (2013). Learn and thou shall thrive: Advancing a model of workplace familism and organizational learning capability in small and medium enterprise (SMEs) manufacturers in Malaysia. Business Strategy Series, 14(5/6), 151-159. 
Jaw, B. S. \& Liu, W. (2003). Promoting organizational learning and self-renewal in Taiwanese companies: the role of HRM. Human Research Management, 42(3), 223-241.

Jerez-Gomez, P., Lorente, J. C. \& Cabrera, R. V. (2005). Organizational learning and compensation strategies: Evidence from the Spanish chemical industry. Human Resource Management, 44(3), 279-299.

Jerez-Gomez, P., Lorente, J. C. \& Cabrera, R. V. (2005). Organizational learning capability: a proposal of measurement. Journal of Business Research, 58, 715-725.

Jimenez-Jimenez, D., Valle, R. S. \& Hernandez-Espallardo, M. (2008). Fostering innovation: the role of market orientation and organizational learning. Innovation Management, 11(3), 389-412.

Jones, G. R. (2000). Organizational Theory. New Jersey: Prentice Hall.

Kang, S. C., Morris, S. S. \& Snell, S. A. (2007). Relational archetypes, organizational learning, and value creation: extending the human resource architecture. Academy of Management Review, 32, 236-256.

Lopez, S. P., Peon, J. M. M. \& Ordas, C. J. V. (2005). Human resource practices, organizational learning and business performance. Human Resource Development International, 8(2), 147-164.

Lopez, S. P., Peon, J. M. M. \& Ordas, C. J. V. (2006).Human resource management as a determining factor in organizational learning. Management Learning, 37(2), 215-239.

Lopez-Cabrales, A., Real, J. C. \& Valle, R. (2011). Relationships between human resource management practices and organizational learning capability: The mediating role of human capital. Personnel Review, 40(3), 344-363.

Malaysia Investment Development Authority (MIDA). (2012). Malaysia investment performance 2011.Kuala Lumpur: Mida

Malaysia Investment Development Authority (MIDA). (2014). Malaysia investment performance 2013.Kuala Lumpur: Mida

Malaysia Productivity Corporation (MPC). (2013). Productivity report 2012/2013. Kuala Lumpur: MPC.

Marwat, Z. A., Arif, M. \& Jan, K. (2009). Impact of selection, training, performance appraisal and compensation on employee performance: A case of Pakistani telecom sector. Interdisciplinary Journal of Contemporary Research In Business, 1(7), 189-189.

Minbaeva, D. B. (2005). HRM practices and MNC knowledge transfer. Personnel Review, 34(1), 125-144.

MohdSamsul, M. S., Norliya, A. K. \& MohdIdzwan, M. S. (2011). Organizational learning capabilities and knowledge performance: A conceptual framework. International Conference on Sociality and Economics Development, Singapore.

Moideenkutty, U., Lamki, A. A. \& Murthy, Y. S. R. (2011). HRM practices and organizational performance in Oman. Personal Review, 40(2), 239-251.

Muhammad Asif, K. (2010).Effects of human resource management practices on organizational performance An empirical study of oil and gas industry in Pakistan. European Journal of Economics, Finance and Administrative Sciences, 24, 157-175.

Nazlina, Z., SitiRohaida, M. \&Aizzat, M. N. (2011). Investigating the role of human resource management practices on the performance of SME: A conceptual framework. Journal of Global Management, 3(1), 74-92.

Noe, R. A., Hollenbeck, J. R., Gerhart, B. \& Wright, P. M. (2004). Fundamentals of human resource management. New York: Mc-Graw-Hill Companies, Inc.

Phillips, J. J. (1997). In action: Measuring return on investment. American Society for Training and Development, 2(5), 12.

Raida, A. A. (2009). Developing future leaders: The contribution of talent management, 1-169 as retrieved from http://www.greenleaf.edu/pdf/raida_al-awamleh.pdf

Raj, R. \& Srivastava, K. B. L. (2013). The mediating role of organizational learning on the relationship among organizational culture, HRM practices and innovativeness. Management and Labor Studies, 38, 201223.

Rhodes, J., Lok, P., Hung, R. Y. Y. \& Fang, S. C. (2008). An integrative model of organizational learning and social capital on effective knowledge transfer and perceived organizational performance. Journal of Workplace Learning, 20(4), 245-258.

Ricardo, R. \& Wade, D. (2001). Corporate Performance Management: How to build a better organization through measurement driven strategies alignment. Oxford, UK: Butterworth Heinemann.

Schermerhorn, J. R. Jr, Hunt, J. M. \& Osborn, R. N. (2002). Organizational Behavior, NJ:Wiley.

Sekaran, U. (2000). Research Methods for Business .A Skill Building Approach (3rd ed.).New York: Wiley. 
Shipton, H., Dawson, J., West, M. \& Patterson, M. (2002). Learning in manufacturing organizations: What factors predict effectiveness? Human Resource Development International, 5(1), 55-57.

Singh, K. (2004). Impact of HR practices on perceived firm performance in India. Asia Pacific Journal of Human Resource, 42(3), 301-317.

Sisson, K. \&Storey, J. (2000). Realities of Human Resource Management: Managing the Employment Relationship. Buckingham: Open University Press.

Snell, S. A., Youndt, M. A. \& Wright, P. M. (1996). Establishing a framework for research in strategic human resource management: Merging resource theory and organizational learning. In G. Ferris (Ed.). Research in Personnel and Human Resources Management, 14, 61-90.

Sony, M. \& Naik, S. (2012). Six sigma, organizational learning and innovation: An integration and empirical examination. International Journal of Quality \& Reliability Management, 29(8), 915-936.

Spicer, D. \& Sadler-Smith, E. (2006).Organizational learning in smaller manufacturing firms. International Small Business Journal, 24(2), 133-158

Stavrou, E. T., Brewster, C. \& Charalambousa, C. (2010). Human resource management and firm performance in Europe through the lens of business systems: Best fit, best practices or both? International Journal of Human Resource Management, 21, 933-962.

Swart, J. \& Kinnie, N. (2010). Organizational learning, knowledge assets and hr practices in professional service firms. Human Resource Management Journal, 20(1), 64-79.

Takeuchi, R., Lepak, D. P., Wang, H. \& Takeuchi, K. (2007). An empirical examination of the mechanisms mediating between high-performance work systems and the performance of Japanese organizations. Journal of Applied Psychology, 92, 1069-1083. doi:10.1037/0021-9010.92.4.1069

Theriou, G. N. \& Chatzoglou, P. D. (2008). Enhancing performance through best HRM practices, organizational learning and knowledge management: A conceptual framework. European Business Review, 20(3), $185-207$.

Trevor, C. O., Barry, G. \& Boudreau, J. W. (1997). Voluntary turnover and job performance: Curvilinearity and the moderating influences of salary growth and promotions. Journal of Applied Psychology, 82(1), 4461.

Tsui, A. S., Pearce, J. L., Porter, L. W. \& Hite, J. P. (1995). Choice of employee-organization relationship: Influence of external and internal organizational factors. In G.R. Ferris (Ed). Research in Personnel and Human Resource Management, 13, 117-151.

Wang, C. (2008). Entrepreneurial orientation, learning orientation and firm performance. Entrepreneurship Theory and Practice, 32, 635-657.

Watkins, K. \& Marsick, V. (1992). Building the learning organization: a new role for human resource developers. Studies in Continuing Education, 14(2), 115-129.

Weldy, T. G. \& William, E. G. (2010). The learning organization: variations at different organizational levels. The Learning Organization, 17(5), 455-470.

Wright, P. M., Dunford, B. B. \& Snell, S. A. (2001). Human resources and the resource based view of the firm. Journal of Management, 27(6), 701-721.

Youndt, M. A., Snell, S. A., Dean, J.W. Jr, \& Lepak, D. P. (1996).Human resource management, manufacturing strategy and firm performance. Academy of Management Journal, 39, 836-866.

Zheng, C., O'Neill, G. \& Morrison, M. (2009). Enhancing Chinese SME performance through innovative HR practices. Personnel Review, 38(2), in press. 